Fasna, M.F.F. and Gunatilake, S., 2019. Energy retrofits to enhance energy performance of existing buildings: A review. In: Sandanayake, Y.G., Gunatilake, S. and Waidyasekara, A. (eds). Proceedings of the $8^{\text {th }}$ World Construction Symposium, Colombo, Sri Lanka, 8-10 November 2019, pp. 308-319. DOI: doi.org/10.31705/WCS.2019.31. Available at: https://2019.ciobwcs.com/papers

\title{
ENERGY RETROFITS TO ENHANCE ENERGY PERFORMANCE OF EXISTING BUILDINGS: A REVIEW
}

\author{
M.F.F. Fasna ${ }^{1}$ and Sachie Gunatilake ${ }^{2}$
}

\begin{abstract}
Inefficient buildings use three to five times the energy as efficient buildings. Herein, improving the Energy Efficiency (EE) of buildings, specifically existing buildings that account for a large part of the building sector, has become a major priority. Energy Retrofits (ER) are identified as the main approach to enhance energy performance of buildings to achieve energy reduction targets. Yet, a general lack of awareness exists with respect to ER, types of ER and the possible ER measures through which building EE could be enhanced. Thus, the aim of this paper is to fill this research gap by critically reviewing the relevant literature on ER. With the intention of avoiding the misperceptions on the concept of ER, the paper first analysed various definitions of ER provided by different authors. This had made it clear that in addition to enhancing EE, $E R$ also result in upgraded functionality, improved architectural quality, increased aesthetic value, reduced resource consumption, decreased $\mathrm{CO}_{2}$ emissions and improved indoor air quality. Besides, based on the critical review of literature, the paper also discusses different types of ER that could be adopted to retrofit a particular building and different ER measures that could be used to retrofit different building elements/systems. The findings of this study could be used by practitioners as a basis in understanding the available ER types and measures for the buildings that would be of use in making effective decisions during their endeavours to enhance the EE of existing buildings.
\end{abstract}

Keywords: Definition; Energy Efficiency (EE); Energy Retrofits (ER); Existing Buildings; Retrofit Measures; Retrofit Types.

\section{INTRODUCTION}

Among the energy end-use sectors, improving the Energy Efficiency (EE) of buildings has become a major global priority (Bertone et al., 2018). This is because, buildings account for almost half of the worldwide energy consumption, together with resultant Greenhouse Gas (GHG) emissions (Liang et al., 2016). Thus, to reach the emissions reduction targets and to enhance the sustainability of the built environment, a shift has to be made towards more energy efficient practices (Rydin et al., 2012).

Within the context of built environment, EE is all about using less energy for operations (i.e. for heating, cooling, lighting and other appliances), without impacting the health and comfort of its occupants (Ruparathna et al., 2016). ESMAP (2014) and Hendron (2013) had disclosed 'improved design and construction' techniques that reduce heating, cooling, ventilating, and lighting loads; 'active management of energy use'; and 'ER' i.e. building upgrades and replacement of energy-using equipment, as the key EE

\footnotetext{
${ }^{1}$ Department of Building Economics, University of Moratuwa, Sri Lanka, fasna.fm2013@gmail.com

2 Department of Building Economics, University of Moratuwa, Sri Lanka, sachieg@uom.lk
} 
improvement approaches to enhance the energy performance of the buildings (i.e. both new and existing buildings) (refer Figure 1). As existing buildings encompass the largest segment of the built environment (Zhou et al., 2016) and have a huge potential for energy saving (Xu et al., 2013), improving the EE of existing buildings is perceived as a crucial step in minimising overall energy use (Panthi et al., 2017) and improving the energy performance (Mohareb and Kennedy, 2014).

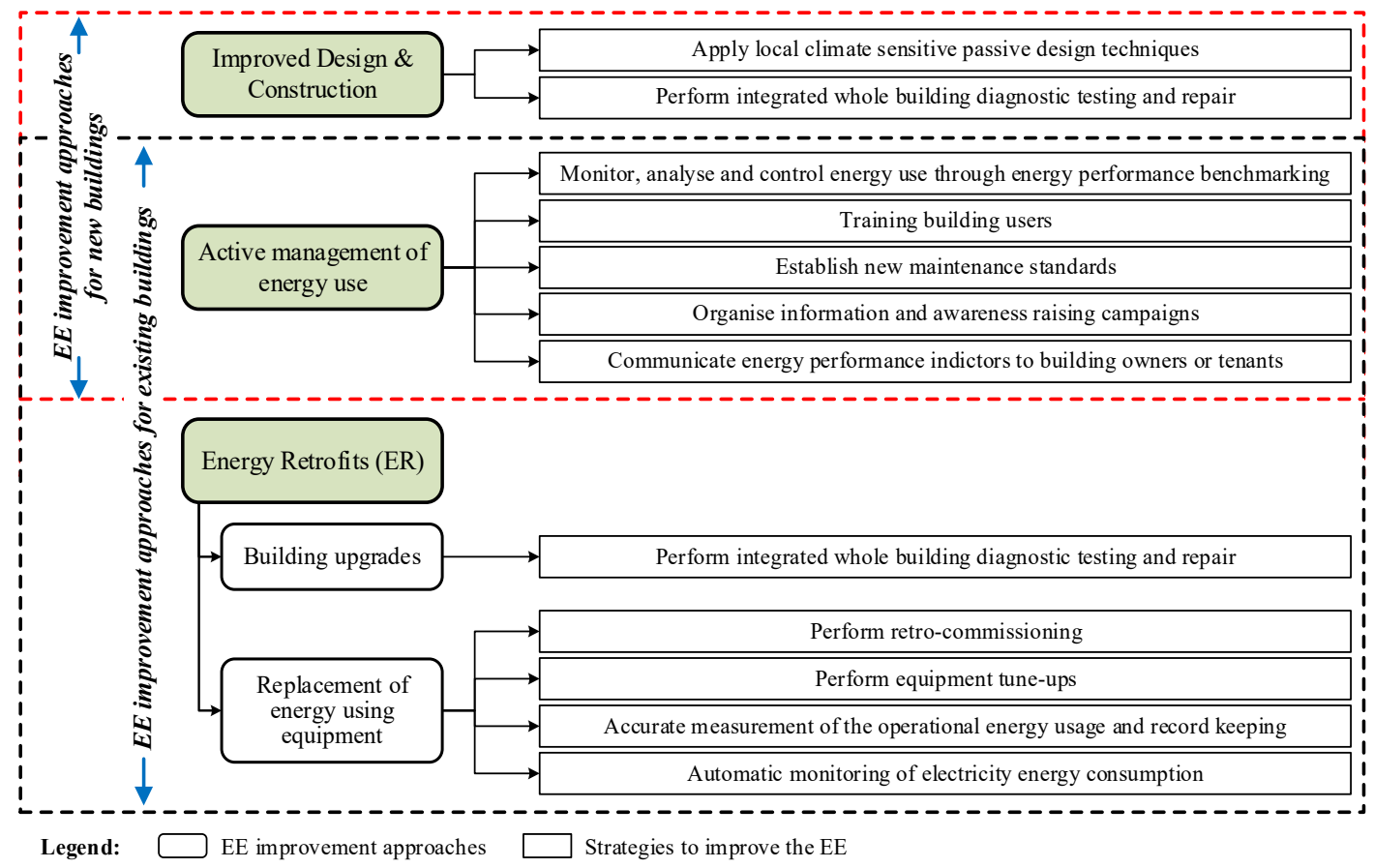

Figure 1: EE improvement approaches to enhance the EE of buildings (Source: Adapted from BASF, 2009; Escrivá-Escrivá, 2011; ESMAP, 2014; Hendron, 2013)

Various studies have made evident that among the two main approaches to enhance the EE of existing buildings, energy consumption in existing buildings can be reduced significantly through adopting ER (Chidiac et al., 2011; Sesana et al., 2016). Hence, retrofitting existing buildings is considered as the key approach to achieve energy reduction targets (Liang et al., 2015) and sustainability in the built environment (Liang et al., 2015; Ma et al., 2012) at relatively low cost and high uptake rates (Ma et al., 2012). However, still there appear to be confusions around conceptualization of ER, ER types and the respective measures that could be adopted under each ER type to enhance energy performance of the built environment. Hence, this paper is aimed at reviewing the existing literature to identify and explore the concept of ER, different types of ER, and available ER measures to enhance the energy performance of the existing buildings. Using these findings as a basis, this paper conceptualises the different ER types and measures that could incentivise the practitioners in determining and implementing the suitable types of ER and measures for a particular built environment.

\section{RESEARCH METHODOLOGY}

A systematic literature review is a vital research methodology that is capable of, synthesizing the existing body of knowledge; creating new knowledge on a wider scale than is possible with empirical studies; and identifying new agendas for future research (Denyer and Tranfield, 2009). This study utilized systematic literature review to achieve 
the aforementioned aim. The methodology adopted to do the systematic literature review is shown in Figure 2, which is found to be in line with the suggestions of Denyer and Tranfield (2009) and Mostafa et al. (2016).

\begin{tabular}{|c|c|c|}
\hline Stage 01 & Stage 02 & Stage 03 \\
\hline $\begin{array}{l}\text { Planning } \\
\text { - Determine the search engines/academic data } \\
\text { bases within which to search articles, } \\
>\text { Google scholar, Scopus, Emerald, and } \\
\text { Science direct } \\
\text { - Determine the filtering criteria }\end{array}$ & $\begin{array}{l}\text { Abstract reviews } \\
\text { - Careful review of abstracts to: } \\
\text { > Select appropriate articles based on their } \\
\text { relevance; } \\
\text { > Eliminate less relevant articles; and } \\
>\text { Avoid duplication }\end{array}$ & $\begin{array}{l}\text { Full text reviews } \\
\text { - Extract facts on; } \\
\quad>\text { ER definition } \\
>\text { EE improvement approaches and strategies } \\
\quad>\text { ER types } \\
>\text { ER measures }\end{array}$ \\
\hline $\begin{array}{l}>\text { Key words: i.e. 'energy efficiency', 'energy } \\
\text { efficiency improvement approaches', } \\
\text { 'retrofits', 'retrofit types', 'retrofit } \\
\text { measures' } \\
>\text { Time period: 1980-2019 } \\
>\text { Publication type: Research articles } \\
\end{array}$ & & $\begin{array}{l}\text { Critical analysis and integration } \\
\text { - Analyse the extracted facts using content } \\
\text { analysis } \\
\text { - The content analysis involves; } \\
\text { >Descriptive analysis } \\
\text { > Thematic analysis }\end{array}$ \\
\hline $\begin{array}{l}\text { Computer search } \\
\text { - Search articles in the predetermined search } \\
\text { engines on the basis of criteria set in previous } \\
\text { step }\end{array}$ & & \\
\hline $\begin{array}{l}\text { Screening } \\
\text { - Screening relevant articles through careful } \\
\text { analysis of 'Titles' and 'Key words' }\end{array}$ & & \\
\hline
\end{tabular}

Figure 2: Research process followed to do the systematic literature review

As depicted in Figure 2, this study followed three stages. The intention of the first two stages were to select appropriate research outputs for the review while the third stage was focused on extracting all the needed facts from the derived articles and synthesising accordingly. Among the available search engines, 'Google Scholar', 'Scopus', 'Emerald', and 'Science direct' were selected for this study, as these domains have been widely used in similar reviews (e.g. Yang et al., 2009). This had also ensured that adequate research outputs were captured for the review. Though there are other numerous alternative terms for retrofits identified in literature including 'commercial property retrofit' (Dixon et al., 2014), 'sustainable retrofit' (Swan et al., 2013), 'EE retrofit' (Xu et al., 2015), and 'green retrofit' (Alm et al., 2005; Liang et al., 2015; Liang et al., 2016), the basic search term adopted to retrieve the research publications under this study was 'retrofit'. Search was conducted for the period from year 2000-2018. By following the three stages indicated in Figure 2, this study derived a total of 90 articles appropriate for this study. The articles were analysed using code based content analysis.

\section{ER DEFINITIONS AND PERSPECTIVES}

When discussing the upgrade of a property's physical characteristics to improve its environmental performance, the terms 'modernisation', 'retrofit' and 'refurbishment' are all used within the literature (Jenkins, 2010). This has led to some confusions regarding the clear-cut difference between retrofit and refurbishment. To avoid such confusions, Kolokotsa et al. (2009) have defined both terms clearly in a literal sense. According to them, the term 'refurbishment' implies the necessary modifications needed to return a building to its original state, whereas 'retrofit' includes the necessary actions that will improve the building's energy and/or environmental performance.

As highlighted by Dixon (2014), in academic literature, there has been much debate over the meaning of 'retrofit' and its distinction since different authors have used different terminologies (refer Section 2). Out of the 90 selected articles, 16 were found to have 
provided definitions for ER (refer Table 1). These definitions were analysed with the intention of setting clear boundaries for the concept of ER.

Table 1: Definitions for ER

\begin{tabular}{|c|c|}
\hline Source & Definitions for ER \\
\hline Alm et al. (2005) & $\begin{array}{l}\text { The process of renovating the systems and structure of a building to improve } \\
\text { efficiency, reduce resource consumption, and create improved Indoor Air } \\
\text { Quality (IAQ) }\end{array}$ \\
\hline $\begin{array}{l}\text { Ashrafian et al. } \\
(2016)\end{array}$ & $\begin{array}{l}\text { The modifications done to the existing building systems and equipment to } \\
\text { enhance the energy performance of the buildings }\end{array}$ \\
\hline Brown et al. (2014) & $\begin{array}{l}\text { Upgrade of the building fabric, systems or controls to improve the energy } \\
\text { performance of the property }\end{array}$ \\
\hline $\begin{array}{l}\text { Energy Efficient } \\
\text { Buildings Hub } \\
{[\mathrm{EEBH}](2012)}\end{array}$ & $\begin{array}{l}\text { An optimally engineered improvement designed for a particular building based } \\
\text { on its unique energy usage profile and potential for energy savings, costs of } \\
\text { proposed energy saving solutions, potential for increased asset valuation, } \\
\text { available financial incentives and resources, owner and occupant needs, and } \\
\text { other factors }\end{array}$ \\
\hline $\begin{array}{l}\text { Han et al. }(2006) \text {, } \\
\text { Sun and Liu } \\
(2007), \text { Xu et al. } \\
(2009),(2015)\end{array}$ & $\begin{array}{l}\text { Projects aimed at reducing the operational energy use in buildings through } \\
\text { building envelope improvement and mechanical systems upgrades, while } \\
\text { preserving the comfort of the indoor environment (i.e. reduce energy } \\
\text { expenditures and minimises emissions) }\end{array}$ \\
\hline $\begin{array}{l}\text { Jafari and Valentin, } \\
\text { (2017), Syal et al. } \\
(2014)\end{array}$ & $\begin{array}{l}\text { Physical or operational change in a building, its energy-consuming equipment, } \\
\text { or its occupants' energy-use behavior to reduce its amount of energy } \\
\text { consumption, and thereby to convert the building to a lower energy consuming } \\
\text { facility }\end{array}$ \\
\hline \multirow[t]{2}{*}{$\begin{array}{l}\text { Jaggs and Palmer } \\
(2000)\end{array}$} & $\begin{array}{l}\text { Actions that allow an upgrade of the building's energy and environmental } \\
\text { performance to a higher standard than was originally planned }\end{array}$ \\
\hline & $\begin{array}{l}\text { Changing or modifying building systems to achieve an improved and desired } \\
\text { energy performance }\end{array}$ \\
\hline Liang et al. (2016) & $\begin{array}{l}\text { Incremental improvement of the fabric and systems of a building with the } \\
\text { primary intention of improving EE and reducing carbon emissions }\end{array}$ \\
\hline $\begin{array}{l}\text { Shanghai Con- } \\
\text { struction and } \\
\text { Transportation } \\
\text { Commission (2008) }\end{array}$ & $\begin{array}{l}\text { Approaches to improve the building envelope and equipment systems, that } \\
\text { reduces building energy use while maintaining the comfort of the building's } \\
\text { indoor environment }\end{array}$ \\
\hline Swan et al. (2013) & $\begin{array}{l}\text { Upgrades to the fabric or systems of a property that may reduce energy use or } \\
\text { generate renewable energy }\end{array}$ \\
\hline Tryson (2016) & Making changes to the elements or components of a building \\
\hline Wilkinson (2011) & $\begin{array}{l}\text { The induced modernisation and improvement of an existing structure/building } \\
\text { due to its degradation and the need to improve EE, architectural appeal and } \\
\text { Indoor Environmental Quality (IEQ) for the benefit of the community }\end{array}$ \\
\hline
\end{tabular}

According to Chunduri (2014), the main aim of ER is to save energy or reduce the usage of energy by changing or modifying the systems, equipment or parts of the building. The analysis of many of the definitions given in Table 1 affirms this viewpoint. However, a few authors like Jafari and Valentin (2017) and Syal et al. (2014) had stated that making changes to occupants' energy-use behavior with the intention of reducing energy 
consumption would also fall within the scope of ER. But, according to ESMAP (2014), this should be considered as a separate EE improvement approach (refer Figure 1). According to Wilkinson (2011), making modifications or upgrades to the existing structure owing to its degradations is also called as ER if it results in enhanced EE. This appear to be contradicting with the perspectives of rest of the authors. By critically reviewing the definition domain of 'retrofit', this study had defined ER as, "any type of upgrade or alterations made to an existing building, either to its elements or systems, with the primary intention of improving its energy performance".

It is vivid from the definitions of ER in existing literature that in addition to the enhancement in EE, ER also results in upgraded functionality (Kalc, 2012), improved the architectural quality (Kalc, 2012; Wilkinson, 2011), increased aesthetic value (EEBH, 2012; Kalc, 2012), reduced resource consumption (Alm et al., 2005), decreased $\mathrm{CO}_{2}$ emissions (Liang et al., 2016) and improved IAQ (Alm et al., 2005; Shanghai Construction and Transportation Commission, 2008; Sun and Liu, 2007; Wilkinson, 2011; Xu et al., 2009, 2015).

\section{ER TYPES AND MEASURES}

ER is an area with a broad scope ranging from minor alterations to major retrofit projects (refer Chunduri, 2014). So far numerous authors have identified various types of ER that can be adopted to enhance building energy performance (Ma et al., 2012). These have been classified in various ways based upon different criteria (refer Chunduri, 2014). Review of literature made it clear that, even though different authors have classified ER in different ways on the basis of different criteria or perspectives, it is still possible to find some commonalities and overlaps among these categories despite the terminology being used. Figure 3 portrays the classification of ER types along with the criteria considered by previous authors as well as the other criteria that can also be a basis in stemming the same classification.

Analysis revealed different terms used by authors such as, existing building commissioning, shallow retrofits, retro commissioning, lite retrofits, and quick wins are all interchangeable with one another. Similarly, standard or staged retrofits, medium scale retrofits, partial retrofits, rational paybacks, and conventional retrofits are ascertained as the substitutable to medium retrofits. Correspondingly, whole building retrofit, comprehensive scale retrofits, integrated design, substantial retrofits, comprehensive retrofits, deep measures and deep energy retrofits are found to be identical with deep retrofits. Hence, it is possible to derive that despite these classifications, ER can be classified mainly in to three types as shallow, medium and deep retrofits, on the basis of 'energy saving', 'effort', 'cost', 'number of building systems', 'payback period', 'scale of the project', and 'parties involved'. Table 2 provides a snapshot of the types of ER along with their unique features compiled from the review of literature.

Detailed evaluations of the classifications given in Table 2 disclosed that even though shallow retrofit is the easiest type of retrofit to be implemented, it provides comparatively lower energy savings. Further, it made it clear that deep retrofit is a combination of many shallow and medium retrofits covering several systems of the building (PNNL and PECI, 2011) and focused on achieving higher energy savings compared to shallow and medium retrofit measures by incorporating a whole-building approach (SEAI, 2015). 


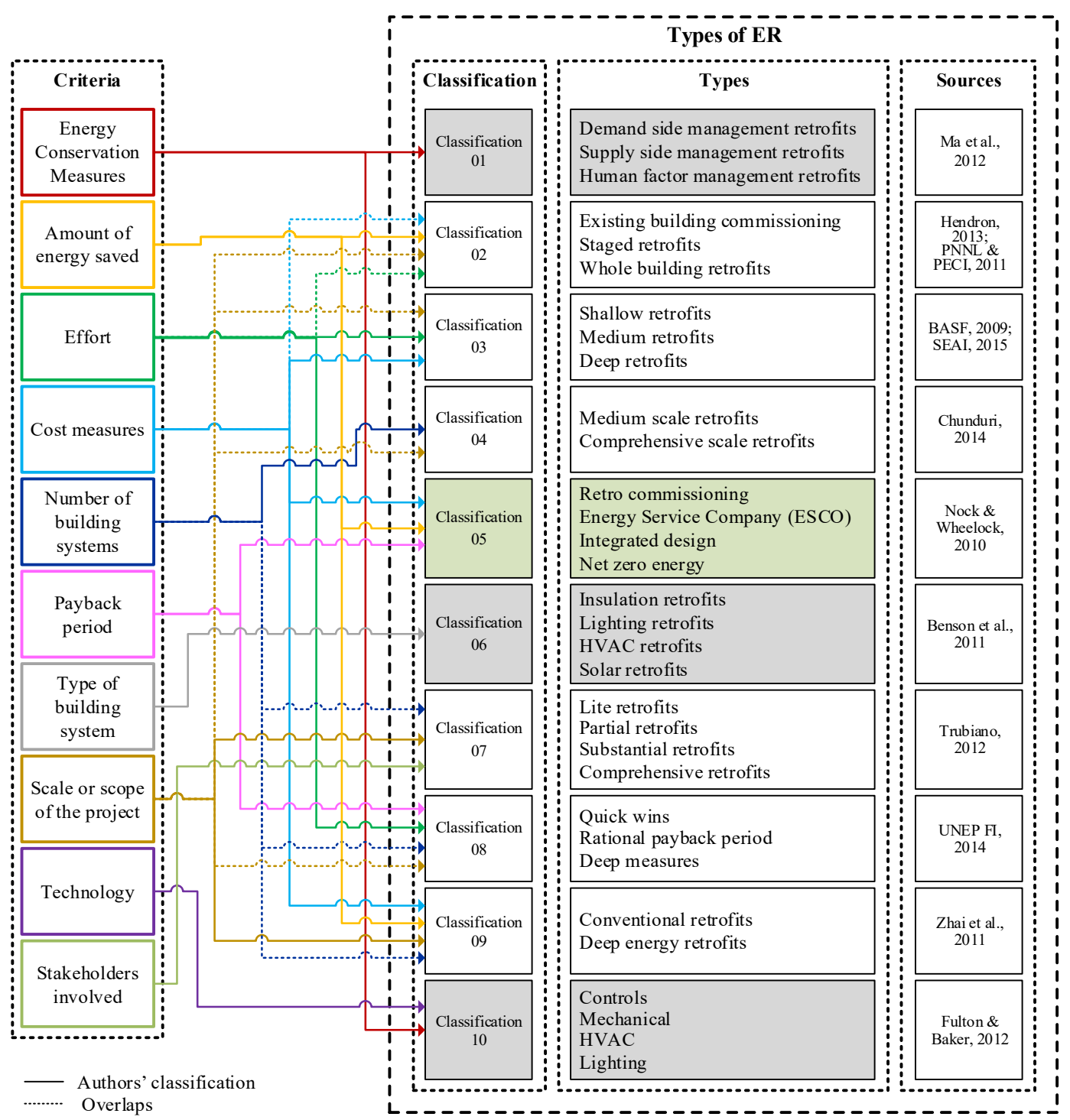

Figure 3: Classifications of ER types based on different criteria

Among the derived classifications of ER (refer Figure 3), Nock and Wheelock (2010) had classified ER into four (i.e. retro commissioning, ESCO, integrated design, and net zero energy) on the basis of energy saving, cost and payback (i.e. classification 6). Among these ER types, the retro commissioning and integrated design are found to be similar to shallow and deep retrofits respectively. It had been ascertained from the literature review that ESCO is a type of stakeholder who tend to execute ER project, while net zero energy is merely an outcome rather an ER type. By considering these facts, in this study the classification of ER by Nock and Wheelock (2010) has not been included.

Table 2: Comparison of shallow, medium, and deep retrofits

\begin{tabular}{llll}
\hline \multirow{2}{*}{ Criteria } & \multicolumn{3}{c}{ ER types } \\
\cline { 2 - 4 } & \multicolumn{1}{c}{ Shallow } & \multicolumn{1}{c}{ Medium } & \multicolumn{1}{c}{ Deep } \\
\hline Energy saving & Up to $15 \%[5]$ & $15-45 \%[3,5,9]$ & $45 \%-60 \%[2,3,4,5,9]$ \\
\hline Effort & $\begin{array}{l}\text { Measures are relatively } \\
\text { easy to install }[3,6]\end{array}$ & $\begin{array}{l}\text { More difficult to } \\
\text { implement }[3,5,6]\end{array}$
\end{tabular}




\begin{tabular}{|c|c|c|c|}
\hline \multirow[t]{2}{*}{ Criteria } & \multicolumn{3}{|c|}{ ER types } \\
\hline & Shallow & Medium & Deep \\
\hline Cost & $\begin{array}{l}\text { Very low upfront cost }[3, \\
4,5,6]\end{array}$ & $\begin{array}{l}\text { Require lower investment } \\
\text { costs [4] }\end{array}$ & $\begin{array}{l}\text { High upfront cost }[2,3,5 \text {, } \\
6]\end{array}$ \\
\hline $\begin{array}{l}\text { Number of } \\
\text { building systems }\end{array}$ & & $\begin{array}{l}2 \text { or more [7] but is } \\
\text { limited to } 2-7[2]\end{array}$ & 7 or more [2] \\
\hline Payback & $\begin{array}{l}\text { Slightly over one year and } \\
\text { less than } 2 \text { years [8] }\end{array}$ & $\begin{array}{l}\text { Less than } 5 \text { years [3] (i.e. } \\
4-5 \text { years [1]) }\end{array}$ & $\begin{array}{l}\text { Longer payback }[2,5] \text { i.e. } \\
\text { more than } 5 \text { years }\end{array}$ \\
\hline Scale or scope & $\begin{array}{l}\text { Limited to retro- } \\
\text { commissioning [7, 8] (i.e. } \\
\text { repair damaged } \\
\text { equipment, weather strip } \\
\text { doors and windows, } \\
\text { improve control strategies } \\
\text { etc. }[4] \text { ) }\end{array}$ & $\begin{array}{l}\text { Adopts a system approach } \\
\text { i.e. upgrade or } \\
\text { replacement of building } \\
\text { systems [1] (An } \\
\text { integrated design } \\
\text { approach is adopted to } \\
\text { some extent }[4,7] \text { ) }\end{array}$ & $\begin{array}{l}\text { Focuses on multiple } \\
\text { building systems }[2,9] \text { and } \\
\text { adopt an integrated design } \\
\text { approach }[2,3,4,7] \\
\text { Involves whole-building } \\
\text { analysis }[2,3,6,8]\end{array}$ \\
\hline Parties involved & $\begin{array}{l}\text { Sub-contractors or } \\
\text { building system suppliers } \\
\text { (Design or engineering } \\
\text { professionals or general } \\
\text { contractors are not } \\
\text { involved) [7] }\end{array}$ & $\begin{array}{l}\text { One or no design \& } \\
\text { engineering } \\
\text { professional(s), with or } \\
\text { without the participation } \\
\text { of the general contractor } \\
\text { [7] }\end{array}$ & $\begin{array}{l}\text { All members of the } \\
\text { Architecture, Engineering } \\
\text { \& Construction community } \\
\text { - design \& engineering } \\
\text { professionals as well as a } \\
\text { general contractor/ project } \\
\text { manager [7] }\end{array}$ \\
\hline
\end{tabular}

[1] BASF, 2009; [2] Chunduri, 2014; [3] ESMAP, 2014; [4] Hendron, 2013; [5] PNNL and PECI, 2011; [6] SEAI, 2015; [7] Trubiano, 2012; [8] UNEP FI, 2014; [9] Zhai et al., 2011

As there are different types of retrofit projects as shown in Figure 3, the ER measure(s) to be used under one project may differ from another. Simply, ER measures (also referred to as 'ER options', 'ER technologies', and 'ER actions') are the actions that can be applied to reduce the energy consumption of buildings (Chidiac et al., 2011) and thereby promote building EE and sustainability (Ma et al., 2012). Currently, a wide range of technological options or solutions are available to increase the EE of buildings (International Finance Corporation Sri Lanka [IFCSL], 2013; Kolokotsa et al., 2009; Mitalidou, 2015; Sri Lanka Energy Managers Association [SLEMA], 2009; Sri Lanka Sustainable Energy Authority [SLSEA], 2008).

As per Xu and Chan (2010), three key retrofit measures for building ER projects are building envelope refurbishment, energy consumption equipment replacement, and Energy Management Systems (EMS) improvement. Hence, it is clear that 'building envelope', 'building services/systems' and 'EMS' are the key areas to be focused when identifying the common ER measures. As building systems like Heating, Ventilation and Air-conditioning (HVAC) and lighting are the dominant energy consuming systems in buildings (Abu-Bakar et al., 2015), during retrofitting priority should be given for lighting and HVAC systems to gain sufficient energy consumption reduction. Thus, during literature review, under 'building services/systems' focus was given towards identifying the ER measures relating to lighting and HVAC systems improvements, as has been highlighted by Doukas et al (2009).

Review of literature disclosed that while selecting the suitable ER measure(s) several key criteria should be considered (e.g. Ma et al., 2012; Menassa and Baer, 2014; Mondrup et 
al., 2014). Figure 4 conceptualises the modified classification of different ER types and common ER measures that could be adopted under ER projects and different criteria to be considered to determine the most suitable ER measures.

As shown in Figure 4, depending on the selected type of ER project, the most suitable ER measure(s) should then be selected. For instance, if HVAC or lighting retrofit is selected under 'demand side management retrofits' (i.e. intended to reduce overall energy demand of a building) or 'medium retrofits', one or few of the ER measures pertinent to the respective building systems to be selected as illustrated in Figure 4. Equally, if an organisation decides to move on with shallow retrofits, among these elicited list of ER measures low cost measures to be selected, while in case of deep retrofits high cost measures that could offer significant savings could be selected, as has been highlighted by SEAI (2015).

As per Duah et al. (2014), to make an informed decision about the most suitable ER measure(s) for a particular building having sufficient and sound knowledge on these retrofit measures is found to be crucial for the building owners and Facilities Managers (FMs). Within this context, it is believed that this developed conceptual framework would facilitate the practitioners.

\section{CONCLUSIONS AND THE WAY FORWARD}

This study provided a full picture of the available EE improvement approaches to enhance the energy performance of buildings along with the respective strategies that could be adopted under each approach (refer Figure 1). Among these derived key EE improvement approaches, building retrofits is ascertained as the best opportunity to improve the EE of the existing buildings. It was revealed that the key intention of ER is to enhance the energy performance of existing buildings mainly through making upgrades or alterations to the building elements or systems. Besides, the paper presents different types of ER projects that would be of use for a particular organisation to determine the suitable type of ER project to be adopted depending on their needs and context. Further, a comprehensive list of different ER measures that can be used enhance the EE of different 'building elements', 'building services/systems' and 'EMS' were also being compiled through the review of articles pertinent to the study arena and presented in this paper (refer Figure 4).

The findings of this study could help industry practitioners to have a better understanding of ER types, possible ER measures, and criteria to be considered in determining the suitable ER measure(s), which would be of use for them during their endeavours to enhance the energy performance of their facilities. Though through compiling different literature sources, the possible ER measures could be identified (refer Figure 4), the level of energy cost reduction and other benefits that could be gained through each of such measures is not well known, which is found to be crucial to make fruitful decisions. Hence, assessing the level of energy saving that could be gained through each of the ER measures found to be a worthy research area.

\section{ACKNOWLEDGEMENT}

The authors would like to acknowledge the support received from the Senate Research Committee of University of Moratuwa, Sri Lanka under the Grant SRC/LT/2018/28. 


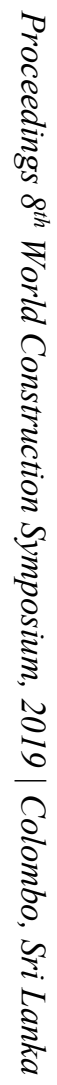

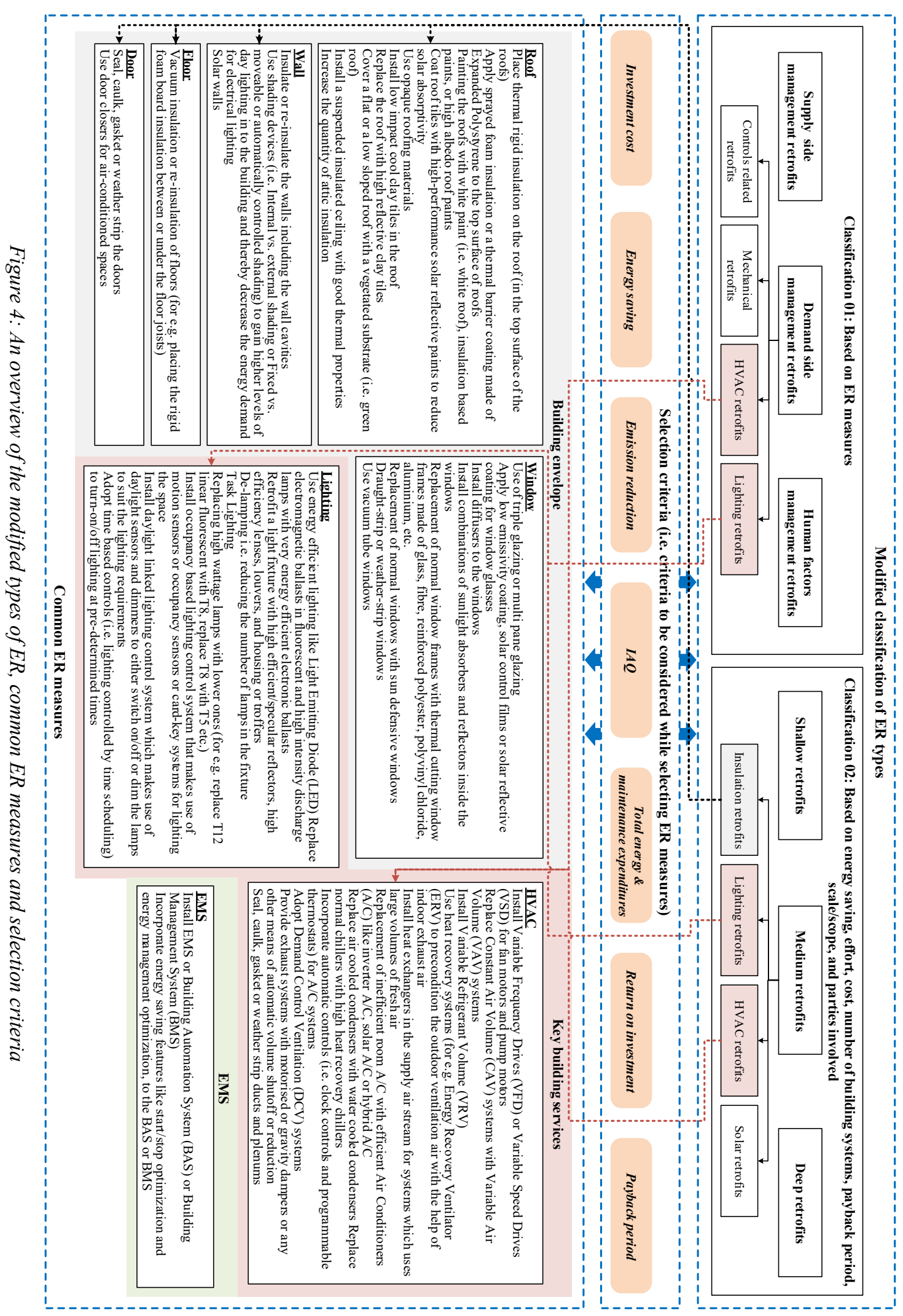

3
7
7
0
0
0
0
0
0
0
0
0
0
0
0
0
0
0
0
0
0 


\section{REFERENCES}

Abu Bakar, N.N., Hassan, M.Y., Abdullah, H., Rahman, H.A., Abdullah, M.P., Hussin, F. and Bandi, M., 2015. Energy efficiency index as an indicator for measuring building energy performance: A review. Renewable and Sustainable Energy Reviews, 44, pp.1-11.

Alm, E., Boland, I., Cobb, V., Eaton, E., Newcomer, M., Pajkowska, J., Zeller, A., 2005. Workshop in applied earth system policy analysis. In Final Workshop Report. New York, NY: Columbia University.

Ashrafian, T., Yilmaz, A.Z., Corgnati, S.P. and Moazzen, N., 2016. Methodology to define cost-optimal level of architectural measures for energy efficient retrofits of existing detached residential buildings in Turkey. Energy and Buildings, 120, pp.58-77.

BASF, 2009. Improving the performance of existing commercial buildings: The chemistry of sustainable retrofits [white paper]. Available from: http://www.construction.basf.us/files/pdf/BASFSustainableRetrofit_whitepaper.pdf

Benson, A., Vargas, E., Bunts, J., Ong, J., Hammond, K., Reeves, L., Duan, P., 2011. Retrofitting commercial real estate: current trends and challenges in increasing building energy efficiency. Available from: https://www.ioes.ucla.edu/wp-content/uploads/retrofitting-commercial-real-estate.pdf

Bertone, E., Stewart, R.A., Sahin, O., Alam, M., Zou, P.X., Buntine, C. and Marshall, C., 2018. Guidelines, barriers and strategies for energy and water retrofits of public buildings. Journal of Cleaner Production, 174, pp.1064-1078.

Brown, P., Swan, W. and Chahal, S., 2014. Retrofitting social housing: reflections by tenants on adopting and living with retrofit technology. Energy Efficiency, 7(4), pp.641-653.

Chidiac, S.E., Catania, E.J., Morofsky, E. and Foo, S., 2011. Effectiveness of single and multiple energy retrofit measures on the energy consumption of office buildings. Energy, 36(8), pp.5037-5052.

Chunduri, S., 2014. Development of planning and design phases of an integrative building life-cycle process model for advanced energy retrofit projects. Thesis (PhD). Available from https://etda.libraries.psu.edu/files/final_submissions/9943

Denyer, D. and Tranfield, D., 2009. Producing a systematic review. In D. A. Buchanan and A. Bryman (Eds.), The Sage Handbook of Organizational Research Methods (pp. 671-689). Thousand Oaks, CA: Sage Publications.

Dixon, T., 2014. Commercial property retrofitting. Journal of Property Investment \& Finance, 32(4), pp.443-452.

Dixon, T., Britnell, J. and Watson, G.B., 2014. 'City-wide' or 'City-blind?' an analysis of emergent retrofit practices in the UK commercial property sector (ISSN 2052-1618). PSRC Retrofit 2050, Cardiff.

Doukas, H., Nychtis, C. and Psarras, J., 2009. Assessing energy-saving measures in buildings through an intelligent decision support model. Building and Environment, 44(2), pp.290-298.

Duah, D.Y., Ford, K. and Syal, M., 2014. Expert knowledge elicitation for decision-making in home energy retrofits. Structural Survey, 32(5), pp.377-395.

Energy Efficient Buildings Hub [EEBH], 2012. Energy Efficient Buildings Hub Five-Year Plan. Philadelphia, PA: EEBH.

Energy Sector Management Assistance Programme [ESMAP], 2014. Improving energy efficiency in buildings (Knowledge $\quad$ series $\quad 019 / 14)$. Available from: https://www.esmap.org/sites/esmap.org/files/DocumentLibrary/ESMAP_Energy_Efficient_MayoralN ote_2014.pdf

Escrivá-Escrivá, G., 2011. Basic actions to improve energy efficiency in commercial buildings in operation. Energy and Buildings, 43(11), pp.3106-3111.

Fulton, M. and Baker, J., 2012. United States building energy efficiency retrofits - Market sizing and financing models. Available from: http://web.mit.edu/cron/project/EESPCambridge/Articles/Finance/Rockefeller\%20and\%20DB\%20-\%20March\%202012\%20\%20Energy\%20Efficiency\%20Market\%20Size\%20and\%20Finance\%20Models.pdf

Han, Z., Liu, C. and Sun, J., 2006. Research on commercial patterns of China existing building energy retrofit based on energy management contract. In Proceeding of International Conference for Enhanced Building Operations (ICEBO). Shenzhen, China. 
Hendron, B., 2013. Advanced Energy Retrofit Guide Practical Ways to Improve Energy Performance Grocery stores. Available from: https://www.nrel.gov/docs/fy13osti/54243.pdf

International Finance Corporation Sri Lanka [IFCSL], 2013. Ensuring sustainability in Sri Lanka's growing hotel industry. Available from: https://www.ifc.org/wps/wcm/connect/30f331004fddd89eb9d8ff23ff966f85/Mapping+Report+++Ens uring+Sustainability+in+Sri+Lanka\%E2\%80\%99s+Hotel+Industry.pdf?MOD=AJPERES

Jafari, A. and Valentin, V., 2017. An optimization framework for building energy retrofits decisionmaking. Building and Environment, 115, pp.118-129.

Jaggs, M. and Palmer, J., 2000. Energy performance indoor environmental quality retrofit - a European diagnosis and decision making method for building refurbishment. Energy \& Buildings, 31(2), pp.97101.

Jenkins, D.P., 2010. The value of retrofitting carbon-saving measures into fuel poor social housing. Energy Policy, 38(2), pp.832-839.

Kalc, I., 2012. Energy Retrofits of Residential Buildings - Impact on Architectural Quality and Occupant's Comfort. Master's thesis. Norwegian University of Science and Technology, Trondheim, Norway).

Kolokotsa, D., Diakaki, C., Grigoroudis, E., Stavrakakis, G. and Kalaitzakis, K., 2009. Decision support methodologies on the energy efficiency and energy management in buildings. Advances in Building Energy Research, 3(1), 121-146.

Liang, X., Peng, Y. and Shen, G.Q., 2016. A game theory based analysis of decision making for green retrofit under different occupancy types. Journal of Cleaner Production, 137, pp.1300-1312.

Liang, X., Shen, G. and Guo, L., 2015. Improving Management of Green Retrofits from a Stakeholder Perspective: A Case Study in China. International Journal of Environmental Research and Public Health, 12(11), pp.13823-13842.

Ma, Z., Cooper, P., Daly, D. and Ledo, L., 2012. Existing building retrofits: Methodology and state-of-theart. Energy and Buildings, 55, pp.889-902.

Menassa, C.C. and Baer, B., 2014. A framework to assess the role of stakeholders in sustainable building retrofit decisions. Sustainable Cities and Society, 10, pp.207-221.

Mitalidou, C., 2015. Energy Efficiency in historic buildings. Master's thesis. International Hellenic University, Thessaloniki, Greece. Available from https://repository.ihu.edu.gr/xmlui/bitstream/handle/11544/12468/Dissertation_MITALIDOU_Signed. pdf? sequence $=1$

Mohareb, E.A. and Kennedy, C.A., 2014. Scenarios of technology adoption towards low-carbon cities. Energy Policy, 66, pp.685-693.

Mondrup, T.F., Karlshøj, J. and Vestergaard, F., 2014. Building Performance Simulation tools for planning of energy efficiency retrofits. In: Arfvidsson, J., Harderup, L., Kumlin, A. and Rosencrantz, B. (eds.), 10th Nordic Symposium on Building Physics. Lund, Sweden: Lund University.

Mostafa, S., Chileshe, N. and Abdelhamid, T., 2016. Lean and agile integration within offsite construction using discrete event simulation. Construction Innovation, 16(4), pp.483-525.

Pacific Northwest National Laboratory [PNNL] and PECI, 2011. Advanced energy retrofit guide: Practical ways to improve energy performance - Office buildings. Available from: https://www.pnnl.gov/main/publications/external/technical_reports/pnnl-20761.pdf

Panthi, K., Das, K. and Abdel-Salam, T., 2017. Sustainability and cost assessment of coastal vacation homes for energy retrofits. Built Environment Project and Asset Management, 7(2), pp.185-198.

Nock, L. and Wheelock, C., 2010. Energy Efficiency Retrofits for Commercial and Public Buildings. Available from: https:/paceworx.com/wpcontent/uploads/srm/pdf/whitepapers/Energy_Efficiency_Retrofits_Pike_Research_Jun09.pdf

Ruparathna, R., Hewage, K. and Sadiq, R., 2016. Improving the energy efficiency of the existing building stock: A critical review of commercial and institutional buildings. Renewable and Sustainable Energy Reviews, 53, pp.1032-1045.

Rydin, Y., Turcu, C., Chmutina, K., Devine-Wright, P., Goodier, C., Guy, S. and Wiersma, B., 2012. Urban energy initiatives: the implications of new urban energy pathways for the UK. Network Industries Quarterly, 14(3), pp.20-23. 
Sesana, M.M., Grecchi, M., Salvalai, G. and Rasica, C., 2016. Methodology of energy efficient building refurbishment: Application on two university campus-building case studies in Italy with engineering students. Journal of Building Engineering, 6, pp.54-64.

Shanghai Construction and Transportation Commission, 2008. Evaluation Standard of Energy Efficiency for Existing Building (DG/TJ 08-2036-2008).

Sri Lanka Sustainable Energy Authority (SLSEA), 2008. Code of practice for energy efficient buildings in Sri Lanka. Colombo, Sri Lanka: SLSEA.

Sri Lanka Energy Managers Association (SLEMA), 2009. Energy management guide. Colombo, Sri Lanka: Sri Lanka Sustainable Energy Authority (SLSEA).

Sun, J.Y. and Liu, C.B., 2007. Obstacle identification and solution on energy efficient retrofit for existing buildings. Low Temperature Architecture Technology, 5, pp.130-131.

Sustainable Energy Authority of Ireland (SEAI), 2015. Unlocking the Energy Efficiency Opportunity Summary for policymakers. Available from: https:/www.seai.ie/resources/publications/Unlocking-theEnergy-Efficiency-Opportunity-Summary-for-Policymakers.pdf

Swan, W., Ruddock, L. and Smith, L., 2013. Low carbon retrofit: attitudes and readiness within the social housing sector. Engineering, Construction and Architectural Management, 20(5), pp.522-535.

Syal, M., Duah, D., Samuel, S., Mazor, M., Mo, Y. and Cyr, T., 2014. Information Framework for Intelligent Decision Support System for Home Energy Retrofits. Journal of Construction Engineering and Management, 140(1), p.04013030.

Trubiano, F., 2012. Integrated design roadmap for advanced energy retrofit. Philadelphia, PA: Penn Design - University of Pennsylvania.

Tryson, L., 2016. Commercial buildings \& the retrofit opportunity. Available from: https://www.contractingbusiness.com/commercial-hvac/commercial-buildings-retrofit-opportunity [Accessed 11 May 2016]

United Nations Environment Programme - Finance Initiative (UNEP FI), 2014. Commercial Real Estate Unlocking the energy efficiency retrofit investment opportunity. Available from: http://www.unepfi.org/fileadmin/documents/Commercial_Real_Estate.pdf

Wilkinson, S., 2011. Sustainable retrofit potential in lower quality office stock in the central business district. In Proceedings of the Management and Innovation for a Sustainable Built Environment Conference, 20-23 June 2011. Amsterdam, Netherlands.

Xu, P.P. and Chan, E.H., 2010. Towards low carbon building: sustainable building energy efficiency retrofit (BEER) under energy performance contracting (EPC) mechanism. In First International Conference on Sustainable Urbanization (ICSU 2010), 15-17 December 2010. Hong Kong.

Xu, P.P., Chan, E.H. and Lam, T.I., 2009. A framework for Energy efficiency retrofits of existing buildings (EEREB) in China. In Proceedings of CRIOCM 2009 International Research Symposium on Advances of Construction Management and Real Estate, 29 Oct - 01 Nov 2009. Nanjing, China.

Xu, P., Chan, E.H.W., Visscher, H.J., Zhang, X. and Wu, Z., 2015. Sustainable building energy efficiency retrofit for hotel buildings using EPC mechanism in China: analytic Network Process (ANP) approach. Journal of Cleaner Production, 107, pp.378-388.

Xu, P., Chan, E.H.W. and Lam, P.T., 2013. A conceptual framework for delivering sustainable building energy efficency retrofit using the Energy Performance Contracting (EPC) in China. Journal of Green Building, 8(1), pp.177-190.

Yang, J., Shen, G.Q., Ho, M., Drew, D.S. and Chan, A.P.C., 2009. Exploring critical success factors for stakeholder management in construction projects. Journal of Civil Engineering and Management, 15(4), pp.337-348.

Zhai, J., LeClaire, N. and Bendewald, M., 2011. Deep energy retrofit of commercial buildings: a key pathway toward low-carbon cities. Carbon Management, 2(4), pp.425-430.

Zhou, Z., Zhang, S., Wang, C., Zuo, J., He, Q. and Rameezdeen, R., 2016. Achieving energy efficient buildings via retrofitting of existing buildings: a case study. Journal of Cleaner Production, 112, pp.3605-3615. 